Article

\title{
Design, Synthesis and Molecular Docking Analysis of Flavonoid Derivatives as Potential Telomerase Inhibitors
}

\author{
Zhan-Fang Fan ${ }^{1,+}$, Sai-Tim Ho ${ }^{2, \dagger}{ }^{+}$, Rui Wen ${ }^{1}$, Ya Fu ${ }^{1}$, Lei Zhang ${ }^{1}$, Jian Wang ${ }^{1}$, Chun Hu ${ }^{1}$, \\ Pang-Chui Shaw ${ }^{2, *}$, Yang Liu ${ }^{1, *} \mathbb{D}$ and Mao-Sheng Cheng ${ }^{1, *}$ \\ 1 Key Laboratory of Structure-Based Drugs Design and Discovery (Ministry of Education), \\ School of Pharmaceutical Engineering, Shenyang Pharmaceutical University, Shenyang 110016, China \\ 2 School of Life Sciences, The Chinese University of Hong Kong, Shatin, Hong Kong, China \\ * Correspondence: pcshaw@cuhk.edu.hk (P.-C.S.); y.liu@syphu.edu.cn (Y.L.); \\ mscheng@syphu.edu.cn (M.-S.C.) \\ + These authors contributed equally to this work.
}

Received: 9 August 2019; Accepted: 31 August 2019; Published: 1 September 2019

\begin{abstract}
Based on the structural scaffolds of natural products, two series of flavonoid derivatives, for a total of twelve compounds, were designed and synthesized as potential human telomerase inhibitors. Using a modified TRAP-PCR assay, compound $5 c$ exhibited the most potent inhibitory activity against human telomerase with an $\mathrm{IC}_{50}$ value of less than $50 \mu \mathrm{M}$. In vitro, the results demonstrated that compound $5 \mathrm{c}$ had potent anticancer activity against five classes of tumor cell lines. The molecular docking and molecular dynamics analyses binding to the human telomerase holoenzyme were performed to elucidate the binding mode of active compound $5 \mathrm{c}$. This finding helps the rational design of more potent telomerase inhibitors based on the structural scaffolds of natural products.
\end{abstract}

Keywords: human telomerase holoenzyme; flavonoid; antiproliferative activity; molecular modeling

\section{Introduction}

Cancer is one of the leading causes of mortality worldwide. Approximately one-third of people are affected by cancer during their lives [1]. In 2018, the American Cancer Society published the global cancer statistics 2018, which estimated that there will be about 18.1 million new cancer cases and 9.6 million cancer deaths worldwide [2]. Lots of studies have indicated that telomerase activity can be detected in approximately $80-90 \%$ cancer cells; however, in somatic cells, this enzyme is relatively low [3,4]. As the community of destiny of telomere, telomerase ensures the indefinite proliferation of cancer cells and has been chosen as a hot target for drug development in cancer therapy [5].

Multiple telomerase inhibitors have been produced, including natural and synthetic products and modified oligonucleotides, through targeting of the catalytic core [5]. In addition, as telomere binding agents, quadruplex ligands (G4) also play a significant role in inhibiting the activity of telomerase [6-8]. Due to the side effects of synthetic products, such as multidrug resistance, toxicity, and poor bioavailability, it is preferred that telomerase inhibitors be isolated from natural plant and marine materials, including secondary metabolites such as polyphenols, alkaloids, terpenoids, xanthones, and sesquiterpenes [9-11]. Among them, flavonoids, as naturally occurring polyphenols, are widely distributed in many field plants and exhibit multitudinous biological and pharmacological properties, for instance, antitumor, cytotoxic, anti-inflammatory, antioxidant, cardiovascular and antidiabetic effects. Several studies have demonstrated that flavonoids can treat and prevent cancer by inhibiting telomerase activity and inducing apoptosis [12-15]. However, few flavonoids compounds 
have been developed into commercially available drugs due to their relatively weak anticancer potency and the uncertain mechanism of action. To date, there is no inhibitor based on the flavonoid skeleton that has been approved by the FDA. Therefore, to explore novel and potent telomerase inhibitors based on the structural scaffolds of natural product flavonoids that have enhanced anticancer activity and can reveal the particular mechanisms remains a challenging task.

As a class of polyhydroxy products, carbohydrates are widespread and ubiquitous in nature and have excellent water solubility and various bioactivities, which have made them a reliable and valuable source for drug design [16]. In addition, the "click reaction", namely the $\mathrm{Cu}(\mathrm{I})$-catalyzed azide-alkyne 1,3-dipolar cycloaddition, has been widely used to construct the 1,2,3-triazoles fragment, which can play an important role in drug design [17]. Moreover, numerous structures and drugs bearing a cinnamoyl moiety have shown strong inhibition against various tumor cell lines [18-21]. Previously, based on natural product design, our group reported a series of triterpenoid saponin derivatives containing a triazole linkage and $N$-acetylglucosamine derivatives substituted with cinnamoyl groups and they all had remarkable antitumor activity both in vitro and in vivo [22-25]. Inspired by these previous results, two series of novel flavonoid derivatives with glycosyl fragments linked by a triazole and containing an $N$-acetylglucosamine substituted with a cinnamoyl group were designed and synthesized to enhance inhibitory ability and elucidate their pharmacological mechanism (Figure 1).



Figure 1. General molecular formulas of two series of flavonoid derivatives.

In this study, we synthesized two series of flavonoid derivatives, for a total of twelve compounds according to the split principle. Telomerase inhibition activity in vitro and antiproliferative activity against five cancer cells lines were assayed to evaluate the possibility of these compounds as potential telomerase inhibitors. Compound $5 \mathrm{c}$ showed the most potent activities both in the telomerase inhibition assay and against all tested cell lines.

To date, for the human telomerase holoenzyme, there is no cocrystallization of protein and ligand complexes available [26]. In this report, the active site of the protein structure was confirmed via alignment with a similar protein discovered from Tribolium castaneum (PDB:5CQG), whose structure is in complex with the highly specific inhibitor BIBR1532 [27]. Then, molecular docking simulations were performed to elucidate the binding mode of active compound $\mathbf{5 c}$.

\section{Results and Discussion}

\subsection{Chemistry}

Six flavonoid derivatives bearing glycosyl and triazole moieties were synthesized. The general synthetic strategy for the formation of the target compounds is shown in Scheme 1. Kaempferol (1), as the starting material, was protected by acetylation to give compound 2. Compound 3 was synthesized via selective deprotection with compound 2 and then allylation to obtain compound 4 . Three azidosaccharide donors $\mathbf{D}_{1}-\mathbf{D}_{3}$ were prepared by the azidation of compounds $\mathbf{C}_{1}-\mathbf{C}_{3}$, which were obtained by bromination of $\mathbf{B}_{1}-\mathbf{B}_{3}$ with $\mathrm{HBr}-\mathrm{AcOH}$. The cyclization of $\mathbf{4}$ with $\mathbf{D}_{\mathbf{1}}-\mathbf{D}_{3}$ through the classic "click-reaction" produced compounds 5a-5c, which were per deacetylated with a catalytic amount of $\mathrm{NaOMe}$ in $\mathrm{CH}_{3} \mathrm{OH}$ to give compounds $\mathbf{6 a - 6}$. 


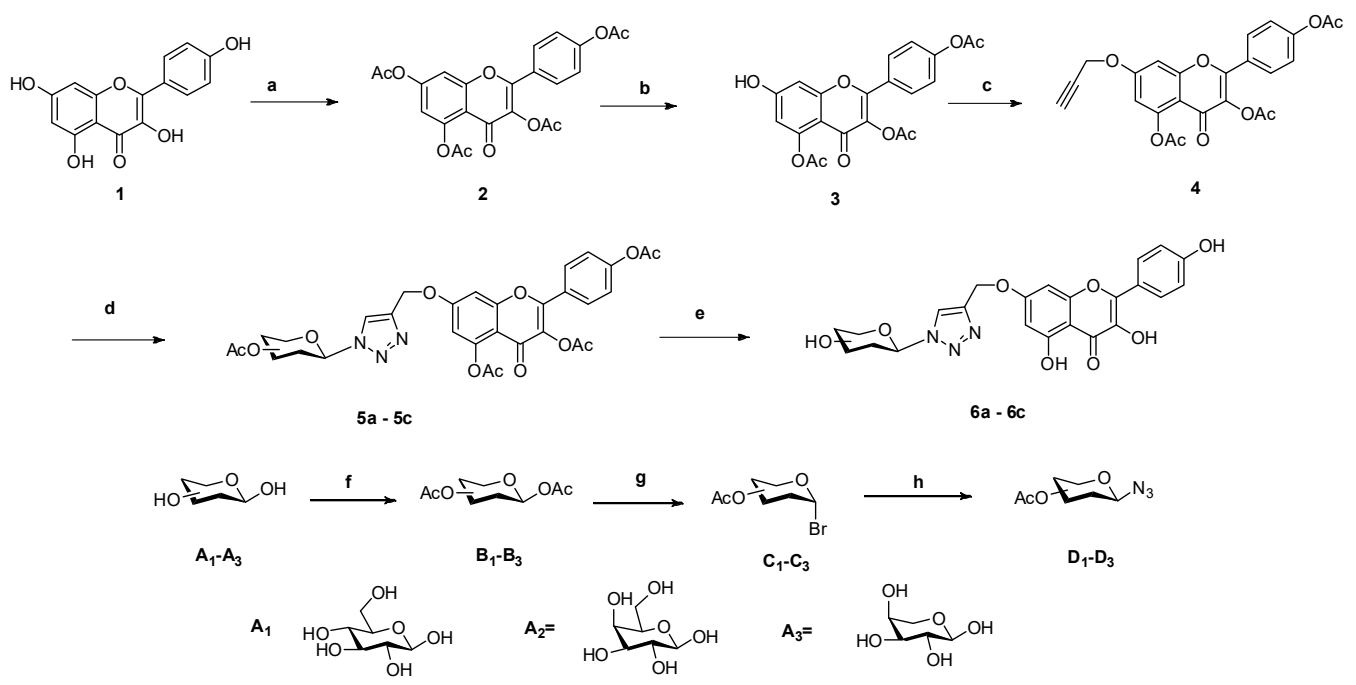

Scheme 1. The synthesis route of compounds $5 \mathbf{a}-\mathbf{- 5 c}$ and $\mathbf{6 a - 6 c}$. Reagent and conditions: (a) $\mathrm{Ac}_{2} \mathrm{O}$, $\mathrm{Et}_{3} \mathrm{~N}, \mathrm{DCM}, 1 \mathrm{~h}$, (b) imidazole, DMF, $0.5 \mathrm{~h}$, (c) propargyl bromide, DMF, $1 \mathrm{~h},(\mathrm{~d}) \mathrm{D}_{\mathbf{1}}-\mathrm{D}_{\mathbf{3}}, \mathrm{CuI}_{\mathrm{I}} \mathrm{Et}_{3} \mathrm{~N}$, acetonitrile, $1 \mathrm{~h}$, (e) $\mathrm{MeOH} / \mathrm{MeONa}, 0.5 \mathrm{~h}$, (f) $\mathrm{Ac}_{2} \mathrm{O}, \mathrm{Et}_{3} \mathrm{~N}$, pyridine, $4 \mathrm{~h}$, (g) $\mathrm{HBr}-\mathrm{AcOH}, \mathrm{DCM}, 2 \mathrm{~h}$, (h) $\mathrm{NaN}_{3}, \mathrm{DMF}, 4 \mathrm{~h}$.

The second series of flavonoid derivatives containing $N$-acetylglucosamine substituted by a cinnamoyl group were synthesized, and the general synthetic route is shown in Scheme 2. Here, compound 7 could be efficiently obtained from intermediate 3 via benzyl protection, followed by deacetylation to give compound 8. Subsequently, treatment of 8 with glycosyl bromide [16] in the presence of molecular sieve led to the formation of $\mathbf{9}$, followed by acetylation to give $\mathbf{1 0}$. Then, to a solution of compound $\mathbf{1 0}$ in acetic acid, zinc powder was added in batches to selectively remove the Troc group to liberate 11. Then, compound 12 was generated by the debenzylation of $\mathbf{1 1}$ catalyzed with $\mathrm{H}_{2}-\mathrm{Pd} / \mathrm{C}$, followed by condensation with substituted cinnamoyl chloride to give compounds 13a-13f. Compounds 14a-14f were obtained by deacetylation of compounds $\mathbf{1 3 a - 1 3 f}$ with $1 \mathrm{~mol} / \mathrm{L} \mathrm{NaOCH}_{3}$ in $\mathrm{CH}_{3} \mathrm{OH}$.

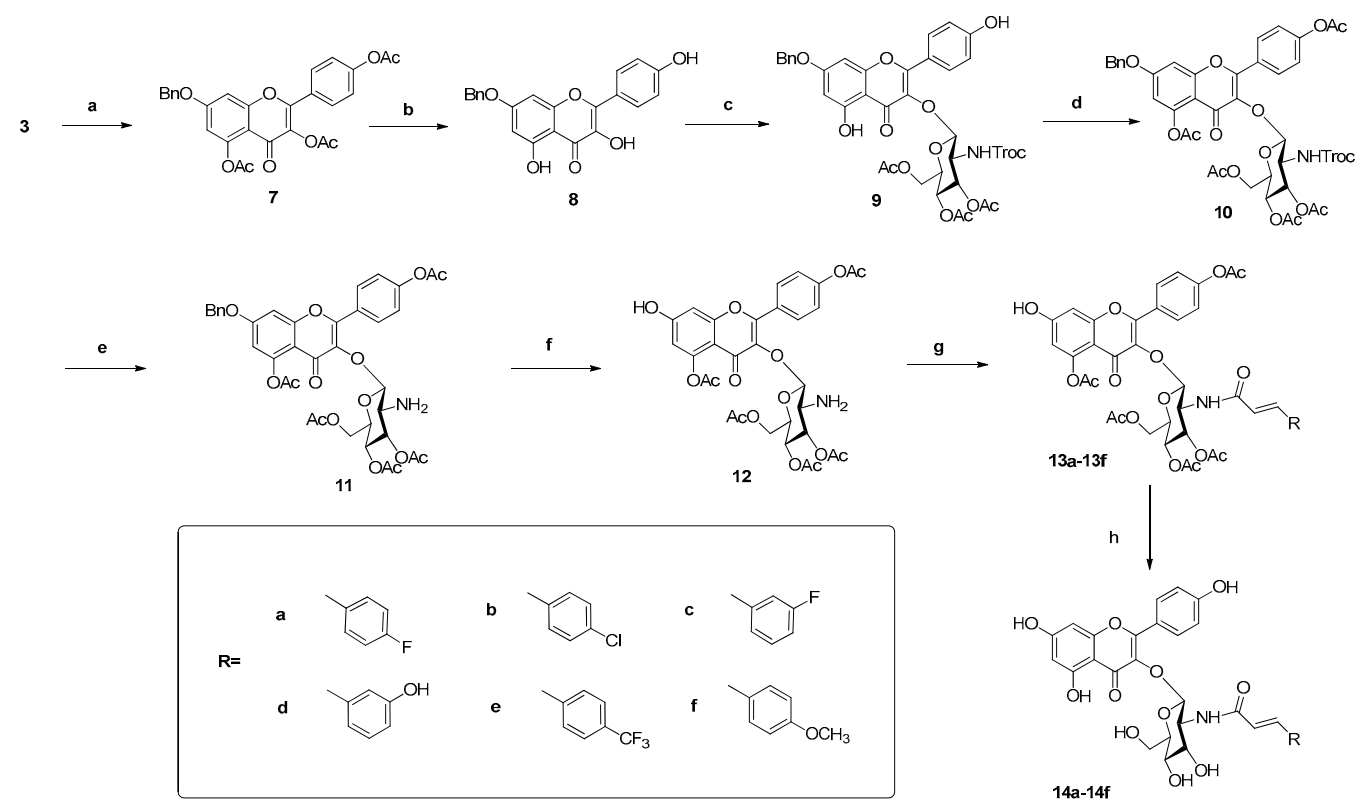

Scheme 2. The synthesis route of compounds 14a-14f. Reagent and conditions: (a) $\mathrm{PhCH}_{2} \mathrm{Br}, \mathrm{DMF}$, 2 h, (b) EtOH, 2 h, (c) glycosyl bromide, $\mathrm{K}_{2} \mathrm{CO}_{3}, \mathrm{DMF}, 5 \mathrm{~h}$, (d) $\mathrm{Ac}_{2} \mathrm{O}, \mathrm{Et}_{3} \mathrm{~N}, \mathrm{DCM}, 1 \mathrm{~h}$, (e) Zinc dust, glacial $\mathrm{AcOH}, 2 \mathrm{~h}$, (f) $\mathrm{H}_{2} / \mathrm{Pd}-\mathrm{C}, \mathrm{MeOH}, 1 \mathrm{~h}$, (g) substituted cinnamoyl chloride, pyridine, dry DCM, $15 \mathrm{~min},(\mathrm{~h}) \mathrm{MeOH} / \mathrm{MeONa}, 0.5 \mathrm{~h}$. 


\subsection{Biological Activity}

\subsubsection{Telomerase Inhibitory Assay}

According to previous reports, the exposed hydroxy group of the flavonoid is a functional group that enhances its anticancer potential [5,13,14]. Herein, compounds $\mathbf{6 a - 6 c}, \mathbf{1 4 a} \mathbf{- 1 4} \mathbf{f}$ were screened for their in vitro telomerase inhibitory activity against HeLa human cervical cancer cells via the telomere repeat amplification protocol-polymerase chain reaction (TRAP-PCR) assay, and compound $5 \mathbf{c}$ was chosen as a control. The results are shown in Figure 2. Unexpectedly, among them, compounds 5c and $\mathbf{1 4}$ e showed potent inhibitory activity against telomerase compared with baicalin as a reference. Surprisingly, compound $5 \mathrm{c}$ showed the most effective activity against telomerase with $\mathrm{IC}_{50}<50 \mu \mathrm{M}$ (baicalin: $\mathrm{IC}_{50}>100 \mu \mathrm{M}$ ). The structure-activity relationship (SAR) of these flavonoid derivatives demonstrated that compounds with acetyl protection displayed potential inhibitory activity.

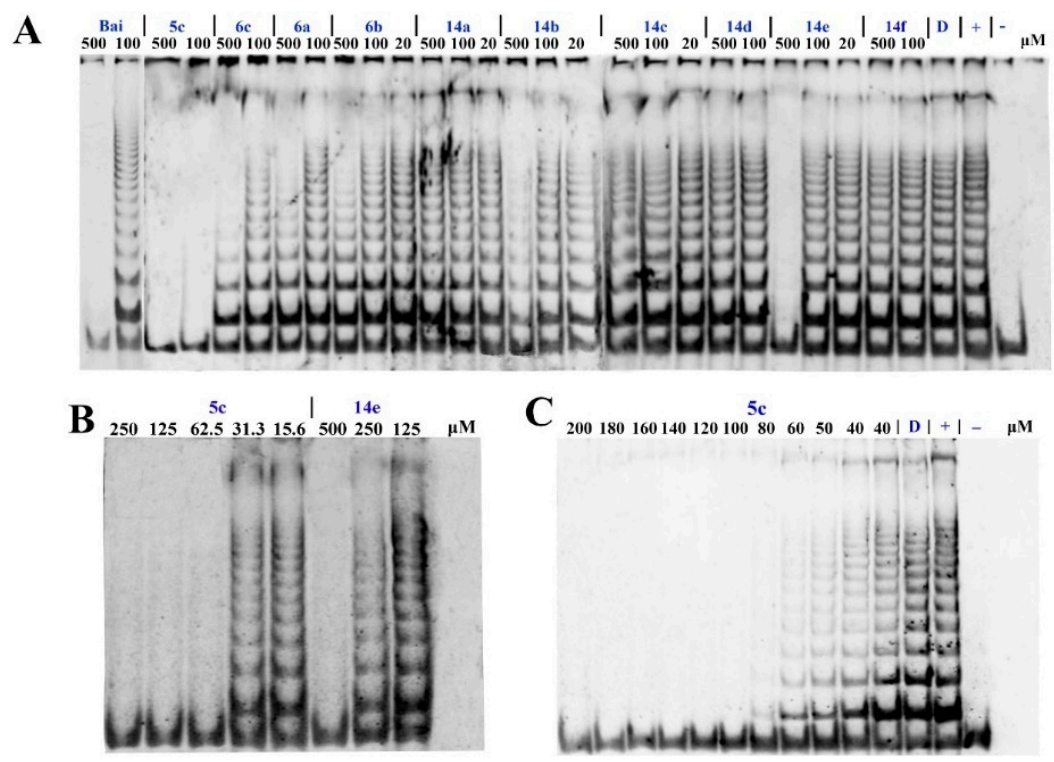

Figure 2. Inhibitory effects of the compounds against telomerase by TRAP-PCR assay. (A) The 10 compounds under different concentrations, baicalin as reference. (B) Compounds $5 \mathrm{c}$ and $14 \mathrm{e}$ under different concentrations. (C) Compound $5 \mathrm{c}$ under different concentrations. [D: DMSO (solvent control); +: contain cell lysate; -: no cell lysate].

\subsubsection{Antiproliferation Assay}

To further explore the structure-activity relationship (SAR) of these compounds and discover the most potent compound, four flavonoid derivatives, $\mathbf{5 c}, \mathbf{6 c}, \mathbf{1 4 b}$ and $\mathbf{1 4 e}$ were evaluated for their antiproliferative activity against human lung cancer cells (A549), human hepatoma cells (HepG2), human cervical cancer cells (HeLa), human gastric cancer cells (MGC-803), and human gastric cancer cells (SGC-7901) by comparison with 5-fluorouracil. The results are summarized in Figure 3 and Table 1.

As shown in Figure 3, these results suggested that compound $\mathbf{5 c}$ was an excellent anticancer agent with potential broad-spectrum anticancer activity compared with the positive control 5-fluorouracil. The anticancer activity of compound $\mathbf{5 c}$ was consistent with the SAR of the telomerase inhibitory activity. It has been demonstrated that the potent anticancer activity of the synthetic compound $\mathbf{5 c}$ is correlated with its telomerase inhibitory activity. 




Figure 3. Antiproliferative activities of compounds 5c, 6c, 14b, and 14e against A549, HepG2, HeLa, MGC-803, and SGC-7901 cell lines.

Table 1. $\mathrm{IC}_{50}$ values $(\mu \mathrm{M})$ of compounds $5 \mathbf{c}, \mathbf{6 c}, \mathbf{1 4 b}$ and $\mathbf{1 4 e}$ against cancer cell lines.

\begin{tabular}{cccccc}
\hline \multirow{2}{*}{ Compound } & \multicolumn{5}{c}{ IC $_{\mathbf{5 0}}$ Values $(\boldsymbol{\mu M})$} \\
\cline { 2 - 6 } & Hela & HepG2 & A549 & MGC-803 & SGC-7901 \\
\hline 5c & $86.183 \pm 2.444$ & $88.149 \pm 0.761$ & $95.842 \pm 0.926$ & $82.992 \pm 3.149$ & $83.421 \pm 1.593$ \\
6c & $>200$ & $>200$ & $>200$ & $>200$ & $>200$ \\
14b & $163.971 \pm 2.253$ & $172.18 \pm 1.881$ & $155.323 \pm 6.627$ & $169.063 \pm 1.676$ & $156.527 \pm 0.914$ \\
$\mathbf{1 4 e}$ & $>200$ & $>200$ & $>200$ & $>200$ & $>200$ \\
5-FU & $110.164 \pm 1.147$ & $110.013 \pm 0.603$ & $105.712 \pm 1.905$ & $95.172 \pm 2.618$ & $96.011 \pm 1.785$ \\
\hline
\end{tabular}

(a) The data represented the mean of three experiments done in triplicate and were expressed as means \pm SD. (b) The $\mathrm{IC}_{50}$ value was defined as the concentration at which $50 \%$ survival of cells was observed. (c) 5 -fluorouracil used as a positive control.

Next, compound $5 \mathbf{c}$ was estimated on two normal human cell lines (Hacat and BEAS-2B). As shown in Table 2, the $\mathrm{IC}_{50}$ values of compound $5 \mathrm{c}$ against the two normal human cells were greater than $200 \mu \mathrm{M}$, which proves that compound $5 \mathrm{c}$ owns its selective effect.

Table 2. $\mathrm{IC}_{50}$ values $(\mu \mathrm{M})$ of compound $5 \mathrm{c}$ against human normal cell lines.

\begin{tabular}{ccc}
\hline \multirow{2}{*}{ Compound } & \multicolumn{2}{c}{ IC $_{50}$ values $(\mu \mathrm{M})$} \\
\cline { 2 - 3 } & Hacat & BEAS-2B \\
\hline $5 c$ & $>200$ & $>200$ \\
\hline
\end{tabular}

Hacat: human immortalized keratinocyte cells; BEAS-2B: human bronchial epithelial cells. Cells were incubated with indicated compound for $48 \mathrm{~h}$ (means $\pm \mathrm{SD}, n=3$ ).

\subsection{Molecular Simulation Analyses}

In 2018, the Kathleen Collins group first presented the cryo-electron microscopy structure of the substrate-bound human telomerase holoenzyme, as well as the PDB coordinates [25]. However, there is no cocrystallization of protein and ligand complexes available. In this report, to evaluate the binding mode of active compound $5 c$ compared with the inactive compound $\mathbf{6 c}$, the active site of the protein structure was confirmed via alignment with a similar protein discovered from T. castaneum (PDB: 5CQG), whose structure is in complex with the highly specific inhibitor BIBR1532. Then, the docked complexes (5c, 6c, and BIBR1532) were chosen and submitted to perform a $100 \mathrm{~ns}$ molecular dynamics (MD) simulation. The dynamic properties of the three complexes were then subjected to analysis of the trajectory data obtained from the $100 \mathrm{~ns}$ MD simulations. The root-mean-square deviation 
(RMSD), root-mean-square fluctuation (RMSF), and protein-ligand contacts were used to evaluate each system in the molecular dynamics studies, as shown in Figures 4-6, respectively. Meanwhile, the superimposition of $\mathbf{5 c}$ and $\mathbf{6 c}$ with BIBR1532 in the active site of telomerase is presented in Figure 7.

As shown in Figure 4, during the simulation, the RMSD value of the BIBR1532/telomerase complex configuration kept increasing until it stabilized at approximately $6.3 \AA$ after 50 ns. Similarly, the RMSD value of the $5 \mathrm{c} /$ telomerase complex finally reached an RMSD plateau at approximately $6.2 \AA$ after $60 \mathrm{~ns}$, although the complex underwent small fluctuations during the periods between 30-50 ns. These results indicated that the BIBR1532/telomerase and 5c/telomerase complexes reached a steady state at the end of the MD simulations. Regrettably, the RMSD value of the $6 \mathrm{c} /$ telomerase complex underwent fluctuations by a large margin until it stabilized at approximately $8.2 \AA$ after $90 \mathrm{~ns}$. The root-mean-square fluctuation (RMSF) plots for BIBR1532 and compounds $\mathbf{5 c}$ and $\mathbf{6 c}$ can explain the local changes in the protein chain during the MD simulations, which are shown in Figure 5. It was obvious that the overall trend of the polylines was substantially similar between BIBR1532 and 5c, indicating that the compound 5c and BIBR1532 had similar stability and mode of interaction.



Figure 4. The root-mean-square fluctuation (RMSD) curve of BIBR1532/telomerase (gray), 5c/telomerase (pink) and 6c/telomerase (blue) complexes.

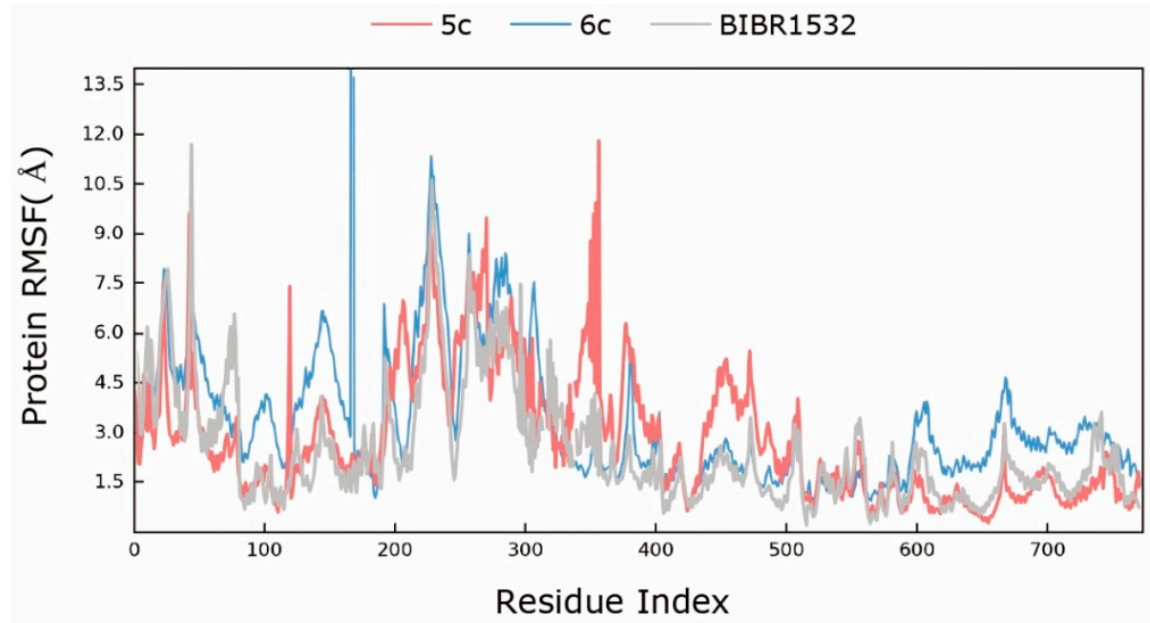

Figure 5. The root-mean-square fluctuation (RMSF) curve of BIBR1532/telomerase (gray), 5c/telomerase (red) and 6c/telomerase (blue) complexes.

As shown in Figure 6, four types of protein-ligand interactions were monitored throughout the MD simulations: hydrogen bonds, hydrophobic interactions, ionic interactions, and water bridges. Analysis of the BIBR1532/telomerase complex trajectory data showed the existence of hydrogen bonds 
between Asn 421, Arg 433, Lys 437 of telomerase and the carbonyl and carboxylic acid groups of BIBR1532. The hydrogen bonds in which Arg 433 participated accounted for $117 \%$ of the entire MD trajectory, indicating that this residue formed more than one hydrogen bond. In addition, the hydrogen bonds formed by Asn 421 and Lys 437 were found to account for $20 \%$ and $21 \%$ of the entire MD trajectory. From the above analysis, we found that the hydrogen-bonding interactions between the carbonyl group and Asn 421, Arg 433 and Lys 437 played significant roles in ligand binding. For hydrophobic contacts, the interactions with Ala 438 were relatively stable and were observed in $72 \%$ of the MD simulations. Several weaker ionic contacts were also found in this complex with Arg 433 and Lys 437 (Figure 6A). From the trajectory analysis of the 5c/telomerase complex, we can see that the kaempferol acetyl moiety of $\mathbf{5 c}$ can mimic the benzoic acid moiety of BIBR1532 and form the key hydrogen bonds with Asn 421 and Lys 437, which accounts for 147\% and 21\%, respectively. Meanwhile, Lys 437 and Phe 434 produced hydrophobic interactions with compound 5c, accounting for $48 \%$ and $32 \%$, respectively (Figure $6 \mathrm{~B}$ ). From the trajectory analysis of the $6 \mathrm{c} /$ telomerase complex, it was not surprising to find that the binding mode changed substantially. Here, it was not hard to see that the key binding interaction was hydrogen bonds between Lys 418 and Asn 424, which has much imparity between the above results (Figure 6C).



Figure 6. Protein-ligand contact interaction over trajectory with respect to BIBR1532 (A), compound 5c (B) and compound $6 \mathrm{c}(\mathrm{C})$.

With deep analysis of the MD simulation results of $\mathbf{5 c}$ and $\mathbf{6 c}$, compared with BIBR1532, the interactions between $\mathbf{5 c}$ and the amino acid residues of telomerase were similar to those of BIBR1532. Conversely, $\mathbf{6 c}$ showed substantial differences as discussed above. All of the above verified that the docking results were accurate (Figures 7 and 8 ) and all the results were consistent with the active in vitro data. 


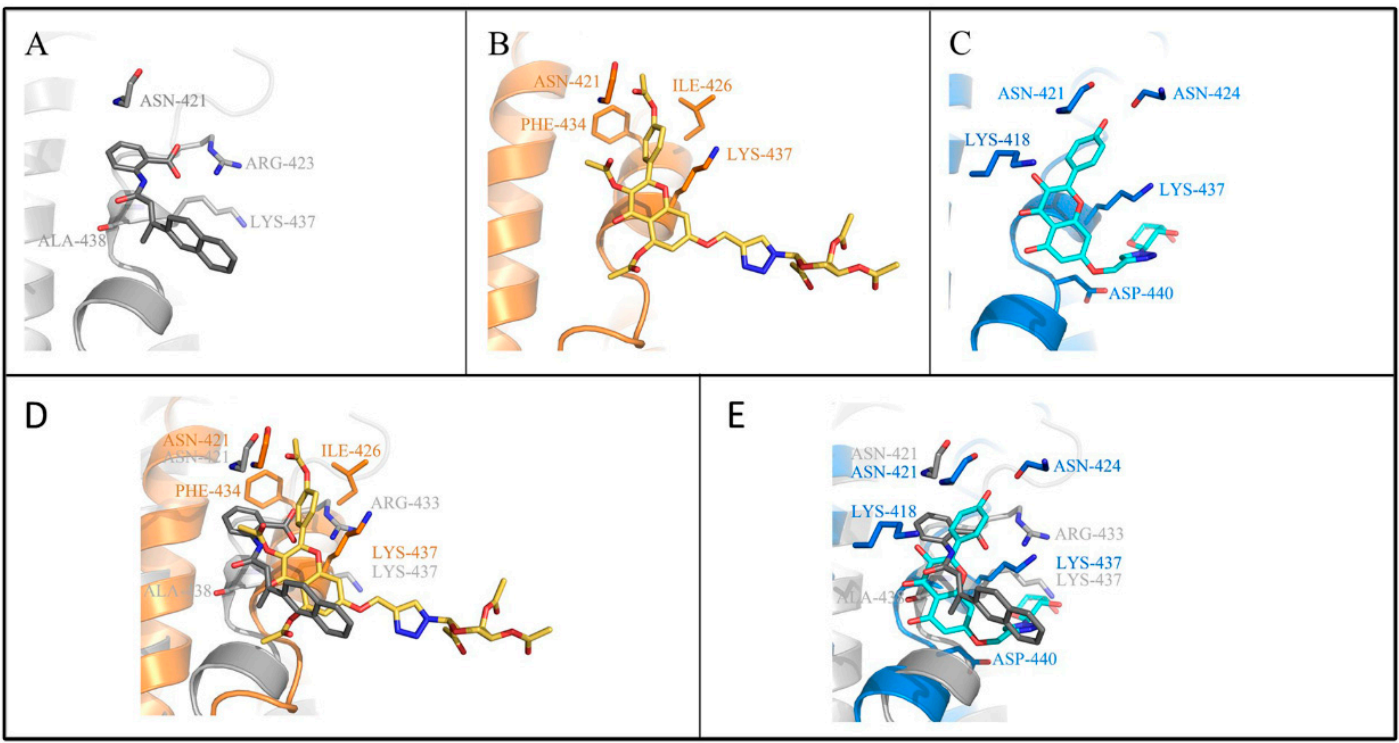

Figure 7. Molecules interact with amino acids in the binding site. Docking of compounds BIBR1532 (A), 5c (B) and $6 \mathrm{c}(\mathrm{C})$ to the active site of telomerase. Superimposing of BIBR1532 (gray) and compound $5 c$ (gold) (D) and 6c (blue) (E) in the active site of telomerase.



Figure 8. Binding mode of compounds with telomerase. (A) 3D ligand interaction diagram of BIBR1532 with telomerase. (B) 3D ligand interaction diagram of compound 5c with telomerase. (C) 3D ligand interaction diagram of compound $6 \mathrm{c}$ with telomerase. (D) 2D ligand interaction diagram of BIBR1532 with telomerase. (E) 2D ligand interaction diagram of compound 5c with telomerase. (F) 2D ligand interaction diagram of compound $6 \mathrm{c}$ with telomerase.

\section{Materials and Methods}

\subsection{Chemistry}

Reagents (Energy Chemical, Shanghai, China) were used without further purification unless otherwise specified. Solvents were dried and redistilled prior to use in the usual way. Analytical TLC was performed using silica gel $\mathrm{HF}_{254}$ (Qingdao Haiyang Chemical, Qingdao, Shandong Province, China). Preparative column chromatography was performed using silica gel $\mathrm{H}$. Melting points were obtained on a Büchi melting point B-540 apparatus. NMR spectra were recorded on a Bruker ARX 
$600 \mathrm{MHz}$ spectrometer (Bruker, Zurich, Zürich, Swiss) with TMS as the internal standard. NMR spectra were analyzed and interpreted using MestreNova (Mestrelab Research, Spain). HRMS were obtained on a Bruker microTOF_Q spectrometer (Agilent, Santa Clara, CA, USA). The gel was stained with SYBR Green I Nuclei A (Invitrogen, Carlsbad, CA, USA) according to the manufacturer's instructions. A Telomerase PCR ELISA kit (Roche, Palo Alto, CA, USA) was used per the manufacturer's instructions.

\subsubsection{General Procedure for the Preparation of Compounds 5a-5c}

To a solution of compound $4(1 \mathrm{~g}, 2.22 \mathrm{mmol})$ and compounds $\mathbf{D}_{\mathbf{1}}-\mathbf{D}_{\mathbf{3}}(2.22 \mathrm{mmol})$ in $20 \mathrm{~mL}$ of acetonitrile, cuprous iodide $(0.845 \mathrm{~g}, 4.44 \mathrm{mmol})$ and triethylamine $(0.925 \mathrm{~mL}, 6.66 \mathrm{mmol})$ were added and the reaction mixture was stirred at room temperature for $1 \mathrm{~h}$. The mixture was quenched by the addition of saturated ammonium chloride solution, followed by extraction with ethyl acetate. The organic layer was washed with brine, dried over anhydrous $\mathrm{Na}_{2} \mathrm{SO}_{4}$, filtered, and the solvent was removed in vacuo. The residue was purified by silica gel column chromatography (petroleum ether: ethyl acetate $=2: 1$ ) to afford compounds $\mathbf{5 a}-\mathbf{5} \mathbf{c}$, the NMR spectrums of compounds $\mathbf{5 a}-\mathbf{5} \mathbf{c}$ were contained in Supplementary Materials.

7-O-((1-(2,3,4,6-tetra-O-acetyl- $\beta$-D-glucopyranosyl)-1H-1,2,3-triazol-4-yl)-methyl)-3,5,4'-tri-O-acetyl-kaempferol (5a): Yellow solid, 87\% yield, m.p. 173.5-175.2 ${ }^{\circ} \mathrm{C} ;{ }^{1} \mathrm{H}-\mathrm{NMR}(600 \mathrm{MHz}$, DMSO-d 6 ) $\delta 8.64(\mathrm{~s}, 1 \mathrm{H}), 7.95$ $(\mathrm{d}, J=8.5 \mathrm{~Hz}, 2 \mathrm{H}), 7.43(\mathrm{~d}, J=2.4 \mathrm{~Hz}, 1 \mathrm{H}), 7.40(\mathrm{~d}, J=8.5 \mathrm{~Hz}, 2 \mathrm{H}), 6.93(\mathrm{~d}, J=2.4 \mathrm{~Hz}, 1 \mathrm{H}), 6.39$ $(\mathrm{d}, J=9.1 \mathrm{~Hz}, 1 \mathrm{H}), 5.68(\mathrm{t}, J=9.3 \mathrm{~Hz}, 1 \mathrm{H}), 5.56(\mathrm{t}, J=9.5 \mathrm{~Hz}, 1 \mathrm{H}), 5.39(\mathrm{~d}, J=2.6 \mathrm{~Hz}, 2 \mathrm{H}), 5.19(\mathrm{t}$, $J=9.7 \mathrm{~Hz}, 1 \mathrm{H}), 4.38(\mathrm{ddd}, J=10.2,5.3,2.3 \mathrm{~Hz}, 1 \mathrm{H}), 4.16-4.07(\mathrm{~m}, 2 \mathrm{H}), 2.32(\mathrm{~d}, J=4.6 \mathrm{~Hz}, 9 \mathrm{H}), 2.03(\mathrm{~s}, 3 \mathrm{H})$, $1.99(\mathrm{~s}, 3 \mathrm{H}), 1.96(\mathrm{~s}, 3 \mathrm{H}), 1.76(\mathrm{~s}, 3 \mathrm{H})$. HRMS (ESI): calcd. for $[\mathrm{M}+\mathrm{H}]^{+} \mathrm{C}_{38} \mathrm{H}_{38} \mathrm{~N}_{3} \mathrm{O}_{18}{ }^{+}$: 824.2150, found 824.2159 .

7-O-((1-(2,3,4,6-tetra-O-acetyl- $\beta$-D-galactopyranosyl)-1H-1,2,3-triazol-4-yl)-methyl)-3,5,4'-tri-O-acetyl-kaempferol (5b): Yellow solid, 87\% yield, m.p. $173.7-175.8{ }^{\circ} \mathrm{C} ;{ }^{1} \mathrm{H}-\mathrm{NMR}\left(600 \mathrm{MHz}, \mathrm{DMSO}-\mathrm{d}_{6}\right) \delta 8.63(\mathrm{~s}, 1 \mathrm{H})$, $7.95(\mathrm{~d}, J=8.8 \mathrm{~Hz}, 2 \mathrm{H}), 7.43(\mathrm{~d}, J=2.5 \mathrm{~Hz}, 1 \mathrm{H}), 7.40(\mathrm{~d}, J=8.8 \mathrm{~Hz}, 2 \mathrm{H}), 6.92(\mathrm{~d}, J=2.5 \mathrm{~Hz}, 1 \mathrm{H}), 6.41$ $(\mathrm{d}, J=9.5 \mathrm{~Hz}, 1 \mathrm{H}), 5.69(\mathrm{t}, J=9.5 \mathrm{~Hz}, 1 \mathrm{H}), 5.57(\mathrm{t}, J=9.7 \mathrm{~Hz}, 1 \mathrm{H}), 5.39(\mathrm{~d}, J=2.6 \mathrm{~Hz}, 2 \mathrm{H}), 5.19(\mathrm{t}, J=9.7 \mathrm{~Hz}$, $1 \mathrm{H}), 4.38(\mathrm{dd}, J=4.4,2.3 \mathrm{~Hz}, 1 \mathrm{H}), 4.09(\mathrm{~m}, 2 \mathrm{H}), 2.32(\mathrm{~d}, J=4.6 \mathrm{~Hz}, 9 \mathrm{H}), 2.03(\mathrm{~s}, 3 \mathrm{H}), 1.99(\mathrm{~s}, 3 \mathrm{H}), 1.96$ (s 3H), 1.76 (s, 3H). HRMS (ESI): calcd. for [M + H] ${ }^{+} \mathrm{C}_{38} \mathrm{H}_{38} \mathrm{~N}_{3} \mathrm{O}_{18}{ }^{+}$: 824.2150, found 824.2201.

7-O-((1-(2,3,4-tri-O-acetyl-a-L-arabinopyranosyl)-1H-1,2,3-triazol-4-yl)-methyl)-3,5,4'-tri-O-acetyl-kaempferol (5c): Yellow solid, 85\% yield, m.p. ${ }^{175.8-176.2 ~}{ }^{\circ} \mathrm{C} ;{ }^{1} \mathrm{H}-\mathrm{NMR}\left(600 \mathrm{MHz}, \mathrm{DMSO}-\mathrm{d}_{6}\right) \delta 8.55(\mathrm{~s}, 1 \mathrm{H})$, $8.00-7.91(\mathrm{~m}, 2 \mathrm{H}), 7.45(\mathrm{~d}, J=2.4 \mathrm{~Hz}, 1 \mathrm{H}), 7.41-7.37(\mathrm{~m}, 2 \mathrm{H}), 6.93(\mathrm{~d}, J=2.4 \mathrm{~Hz}, 1 \mathrm{H}), 6.18(\mathrm{~d}, J=9.2 \mathrm{~Hz}$, $1 \mathrm{H}), 5.60(\mathrm{t}, J=9.6 \mathrm{~Hz}, 1 \mathrm{H}), 5.41(\mathrm{dd}, J=10.2,3.6 \mathrm{~Hz}, 1 \mathrm{H}), 5.37(\mathrm{~s}, 2 \mathrm{H}), 5.32(\mathrm{dt}, J=3.4,1.5 \mathrm{~Hz}, 1 \mathrm{H})$, $4.21-4.16(\mathrm{~m}, 1 \mathrm{H}), 4.05(\mathrm{dd}, J=13.2,1.9 \mathrm{~Hz}, 1 \mathrm{H}), 2.39-2.24(\mathrm{~m}, 9 \mathrm{H}), 2.16(\mathrm{~s}, 3 \mathrm{H}), 1.95(\mathrm{~s}, 3 \mathrm{H}), 1.78(\mathrm{~s}, 3 \mathrm{H})$. HRMS (ESI): calcd. for [M + H] ${ }^{+} \mathrm{C}_{35} \mathrm{H}_{34} \mathrm{~N}_{3} \mathrm{O}_{16}{ }^{+}:$752.1939, found 752.1953 .

\subsubsection{General Procedure for the Preparation of Compounds 6a-6c}

To a solution of compounds $\mathbf{5 a}-\mathbf{5 c}(1 \mathrm{~g})$ in $30 \mathrm{~mL}$ of DCM- $\mathrm{CH}_{3} \mathrm{OH}(1: 1)$, freshly prepared $\mathrm{NaOMe}$ in $\mathrm{MeOH}$ solution $(1.0 \mathrm{~mol} / \mathrm{L}, 2.5$ eq.) was added dropwise with stirring. After $0.5 \mathrm{~h}$, the mixture was neutralized with Dowex $\mathrm{H}^{+}$resin to $\mathrm{pH} 7$ and then filtered. The filtrate was concentrated and purified by silica gel column chromatography (DCM:MeOH $=8: 1$ ) to afford compounds $6 \mathbf{a}-\mathbf{6 c}$, the NMR spectrums of compounds $\mathbf{6 a - 6} \mathbf{c}$ were contained in Supplementary Materials.

7-O-((1-( $\beta$-D-glucopyranosyl)-1H-1,2,3-triazol-4-yl)-methyl)-kaempferol (6a): Yellow solid, 45\% yield, m.p. 175.8-176.2 ${ }^{\circ} \mathrm{C} ;{ }^{1} \mathrm{H}-\mathrm{NMR}\left(600 \mathrm{MHz}, \mathrm{DMSO}_{-} \mathrm{d}_{6}\right) \delta 12.49(\mathrm{~s}, 1 \mathrm{H}), 10.16(\mathrm{~s}, 1 \mathrm{H}), 9.51(\mathrm{~s}, 1 \mathrm{H}), 8.49(\mathrm{~s}, 1 \mathrm{H})$, $8.08(\mathrm{~d}, J=8.9 \mathrm{~Hz}, 2 \mathrm{H}), 6.95(\mathrm{~d}, J=8.9 \mathrm{~Hz}, 2 \mathrm{H}), 6.92(\mathrm{~d}, J=2.2 \mathrm{~Hz}, 1 \mathrm{H}), 6.45(\mathrm{~d}, J=2.2 \mathrm{~Hz}, 1 \mathrm{H}), 5.57$ $(\mathrm{d}, J=9.2 \mathrm{~Hz}, 1 \mathrm{H}), 5.42(\mathrm{~d}, J=5.9 \mathrm{~Hz}, 1 \mathrm{H}), 5.29(\mathrm{~s}, 1 \mathrm{H}), 5.28(\mathrm{~s}, 2 \mathrm{H}), 5.16(\mathrm{~d}, J=5.2 \mathrm{~Hz}, 1 \mathrm{H}), 4.62$ $(\mathrm{t}, J=5.5 \mathrm{~Hz}, 1 \mathrm{H}), 3.78(\mathrm{td}, J=9.1,5.8 \mathrm{~Hz}, 1 \mathrm{H}), 3.69(\mathrm{dd}, J=9.9,5.7 \mathrm{~Hz}, 1 \mathrm{H}), 3.49-3.35(\mathrm{~m}, 4 \mathrm{H})$. HRMS (ESI): calcd. for [M+ H] $]^{+} \mathrm{C}_{24} \mathrm{H}_{24} \mathrm{~N}_{3} \mathrm{O}_{11}{ }^{+}$: 530.1411, found 530.1423 . 
7-O-((1-( $\beta$-D-galactopyranosyl)-1H-1,2,3-triazol-4-yl)-methyl)-kaempferol (6b): Yellow solid, 47\% yield, m.p. 175.8-176.2 ${ }^{\circ} \mathrm{C} ;{ }^{1} \mathrm{H}-\mathrm{NMR}\left(600 \mathrm{MHz}, \mathrm{DMSO}^{\mathrm{d}} \mathrm{d}_{6}\right) \delta 12.49(\mathrm{~s}, 1 \mathrm{H}), 10.13(\mathrm{~s}, 1 \mathrm{H}), 9.51(\mathrm{~s}, 1 \mathrm{H}), 8.43(\mathrm{~s}, 1 \mathrm{H})$, $8.09(\mathrm{~d}, J=8.5 \mathrm{~Hz}, 2 \mathrm{H}), 6.95(\mathrm{~d}, J=8.9 \mathrm{~Hz}, 2 \mathrm{H}), 6.92(\mathrm{~d}, J=2.8 \mathrm{~Hz}, 1 \mathrm{H}), 6.46(\mathrm{~d}, J=2.2 \mathrm{~Hz}, 1 \mathrm{H}), 5.52$ $(\mathrm{d}, J=9.1 \mathrm{~Hz}, 1 \mathrm{H}), 5.29(\mathrm{~s}, 2 \mathrm{H}), 5.26(\mathrm{~d}, J=7.6 \mathrm{~Hz}, 1 \mathrm{H}), 5.02(\mathrm{~d}, J=5.7 \mathrm{~Hz}, 1 \mathrm{H}), 4.06(\mathrm{td}, J=9.3,5.9 \mathrm{~Hz}$, $1 \mathrm{H}), 3.75(\mathrm{dt}, J=20.0,5.1 \mathrm{~Hz}, 2 \mathrm{H}), 3.59-3.43(\mathrm{~m}, 3 \mathrm{H})$. HRMS (ESI): calcd. for $[\mathrm{M}+\mathrm{H}]^{+} \mathrm{C}_{24} \mathrm{H}_{24} \mathrm{~N}_{3} \mathrm{O}_{11}{ }^{+}$: 530.1411 , found 530.1364 .

7-O-((1-(a-L-arabinopyranosyl)-1H-1,2,3-triazol-4-yl)-methyl)-kaempferol (6c): Yellow solid, 42\% yield, m.p. 175.8-176.2 ${ }^{\circ} \mathrm{C}$; ${ }^{1} \mathrm{H}-\mathrm{NMR}(600 \mathrm{MHz}, \mathrm{DMSO}-\mathrm{d} 6) \delta 12.48(\mathrm{~s}, 1 \mathrm{H}), 10.12(\mathrm{~s}, 1 \mathrm{H}), 9.51(\mathrm{~s}, 1 \mathrm{H}), 8.41(\mathrm{~s}, 1 \mathrm{H})$, $8.08(\mathrm{~d}, J=8.9 \mathrm{~Hz}, 2 \mathrm{H}), 6.94(\mathrm{~d}, J=8.9 \mathrm{~Hz}, 2 \mathrm{H}), 6.91(\mathrm{~d}, J=2.2 \mathrm{~Hz}, 1 \mathrm{H}), 6.45(\mathrm{~d}, J=2.2 \mathrm{~Hz}, 1 \mathrm{H}), 5.45$ $(\mathrm{d}, J=9.1 \mathrm{~Hz}, 1 \mathrm{H}), 5.29(\mathrm{~s}, 2 \mathrm{H}), 5.01(\mathrm{~d}, J=5.8 \mathrm{~Hz}, 1 \mathrm{H}), 4.79(\mathrm{~d}, J=4.5 \mathrm{~Hz}, 1 \mathrm{H}), 4.05(\mathrm{td}, J=9.2,5.8 \mathrm{~Hz}$, $1 \mathrm{H}), 3.85-3.71(\mathrm{~m}, 3 \mathrm{H}), 3.56(\mathrm{ddd}, J=9.2,5.6,3.3 \mathrm{~Hz}, 1 \mathrm{H}), 3.16(\mathrm{~d}, J=4.7 \mathrm{~Hz}, 1 \mathrm{H})$. HRMS (ESI): calcd. for $[\mathrm{M}+\mathrm{H}]^{+} \mathrm{C}_{23} \mathrm{H}_{22} \mathrm{~N}_{3} \mathrm{O}_{10}{ }^{+}$: 500.1305, found 500.1298.

\subsubsection{General Procedure for the Preparation of Compounds 14a-14f}

To a solution of compound $12(0.4 \mathrm{~g}, 0.6 \mathrm{mmol})$ and pyridine $(2.5 \mathrm{~mL})$ in $10 \mathrm{~mL}$ dry DCM, substituted cinnamoyl chloride $(1.32 \mathrm{mmol})$ was added dropwise at room temperature, and the reaction mixture stirred for $15 \mathrm{~min}$. The organic layer was washed with water, saturated sodium hydrogen carbonate, and brine, dried over anhydrous $\mathrm{Na}_{2} \mathrm{SO}_{4}$, filtered, and the solvent was removed in vacuo. The residue was concentrated and purified by silica gel column chromatography (petroleum ether: ethyl acetate $=5: 1$ ) to obtain compounds 13a-13f. To a solution of 13a-13f in $20 \mathrm{~mL} \mathrm{DCM}-\mathrm{CH}_{3} \mathrm{OH}$ (1:1), a $1.0 \mathrm{~mol} / \mathrm{L}$ of $\mathrm{NaOMe}$ in $\mathrm{MeOH}$ solution (2.5 eq) was added dropwise with stirring. After $0.5 \mathrm{~h}$, the mixture was neutralized with Dowex $\mathrm{H}^{+}$resin to $\mathrm{pH} 7$ and then filtered. The filtrate was removed in vacuo and the residue was purified by silica gel column chromatography (DCM:MeOH $=8: 1$ ) to afford compounds 14a-14f, the NMR spectrums of compounds 14a-14f were contained in Supplementary Materials.

3-O-(2-deoxy-2-((3-(4-fluorophenyl)-1-oxo-2-propenyl)amino)- $\beta$-D-glucopyranosyl)-kaempferol (14a): Yellow solid, $45 \%$ yield, m.p. $175.8-176.2{ }^{\circ} \mathrm{C} ;{ }^{1} \mathrm{H}-\mathrm{NMR}\left(600 \mathrm{MHz}, \mathrm{DMSO}-\mathrm{d}_{6}\right) \delta: 12.65(\mathrm{~s}, 1 \mathrm{H}), 11.11(\mathrm{~s}, 1 \mathrm{H})$, $10.38(\mathrm{~s}, 1 \mathrm{H}), 8.29(\mathrm{~d}, J=8.8 \mathrm{~Hz}, 1 \mathrm{H}), 8.11(\mathrm{~d}, J=8.8 \mathrm{~Hz}, 2 \mathrm{H}), 7.62(\mathrm{dd}, J=8.5,5.8 \mathrm{~Hz}, 2 \mathrm{H}), 7.41$ $(\mathrm{d}, J=15.7 \mathrm{~Hz}, 1 \mathrm{H}), 7.25(\mathrm{t}, J=8.9 \mathrm{~Hz}, 2 \mathrm{H}), 6.92(\mathrm{~d}, J=7.5 \mathrm{~Hz}, 2 \mathrm{H}), 6.62(\mathrm{~d}, J=15.6 \mathrm{~Hz}, 1 \mathrm{H}), 6.49$ $(\mathrm{s}, 1 \mathrm{H}), 6.23(\mathrm{~s}, 1 \mathrm{H}), 5.70(\mathrm{~d}, J=8.4 \mathrm{~Hz}, 1 \mathrm{H}), 5.16(\mathrm{~d}, J=3.1 \mathrm{~Hz}, 2 \mathrm{H}), 4.42-4.34(\mathrm{~m}, 1 \mathrm{H}), 3.89(\mathrm{~m}, 1 \mathrm{H})$, $3.57(\mathrm{~m}, 1 \mathrm{H}), 3.43(\mathrm{dd}, J=9.9,6.1 \mathrm{~Hz}, 2 \mathrm{H}), 3.16(\mathrm{~d}, J=5.2 \mathrm{~Hz}, 2 \mathrm{H})$. HRMS (ESI): calcd. for $[\mathrm{M}+\mathrm{H}]^{+}$ $\mathrm{C}_{30} \mathrm{H}_{27} \mathrm{FNO}_{11}{ }^{+}$: 596.1568, found 596.1549.

3-O-(2-deoxy-2-((3-(4-chlorophenyl)-1-oxo-2-propenyl)amino)- $\beta$-D-glucopyranosyl)-kaempferol (14b): Yellow solid, 35\% yield, m.p. 198.2-199.7 ${ }^{\circ} \mathrm{C} ;{ }^{1} \mathrm{H}-\mathrm{NMR}\left(600 \mathrm{MHz}, \mathrm{DMSO}-\mathrm{d}_{6}\right) \delta 12.66(\mathrm{~s}, 1 \mathrm{H}), 10.93(\mathrm{~s}, 1 \mathrm{H})$, $10.25(\mathrm{~s}, 1 \mathrm{H}), 8.28(\mathrm{~d}, J=9.2 \mathrm{~Hz}, 1 \mathrm{H}), 8.12(\mathrm{~d}, J=9.0 \mathrm{~Hz}, 2 \mathrm{H}), 7.60(\mathrm{~d}, J=8.6 \mathrm{~Hz}, 2 \mathrm{H}), 7.48(\mathrm{~d}, J=8.6 \mathrm{~Hz}$, $2 \mathrm{H}), 7.41(\mathrm{~d}, J=15.8 \mathrm{~Hz}, 1 \mathrm{H}), 6.94-6.89(\mathrm{~m}, 2 \mathrm{H}), 6.68(\mathrm{~d}, J=15.8 \mathrm{~Hz}, 1 \mathrm{H}), 6.46(\mathrm{~d}, J=2.1 \mathrm{~Hz}, 1 \mathrm{H}), 6.20$ $(\mathrm{d}, J=2.1 \mathrm{~Hz}, 1 \mathrm{H}), 5.71(\mathrm{~d}, J=8.4 \mathrm{~Hz}, 1 \mathrm{H}), 5.10(\mathrm{t}, J=4.6 \mathrm{~Hz}, 2 \mathrm{H}), 4.32(\mathrm{t}, J=5.6 \mathrm{~Hz}, 1 \mathrm{H}), 3.95-3.84$ $(\mathrm{m}, 1 \mathrm{H}), 3.59-3.55(\mathrm{~m}, 1 \mathrm{H}), 3.46-3.42(\mathrm{~m}, 1 \mathrm{H}), 3.36(\mathrm{~s}, 1 \mathrm{H}), 3.13(\mathrm{td}, J=6.6,5.5,3.5 \mathrm{~Hz}, 2 \mathrm{H})$. HRMS (ESI): calcd. for $[\mathrm{M}+\mathrm{H}]^{+} \mathrm{C}_{30} \mathrm{H}_{27} \mathrm{ClNO}_{11}{ }^{+}$: 612.1273, found 612.1306.

3-O-(2-deoxy-2-((3-(3-fluorophenyl)-1-oxo-2-propenyl)amino)- $\beta$-D-glucopyranosyl)-kaempferol (14c): Yellow solid, 30\% yield, m.p. $181.8-183.2{ }^{\circ} \mathrm{C} ;{ }^{1} \mathrm{H}-\mathrm{NMR}\left(600 \mathrm{MHz}, \mathrm{DMSO}-\mathrm{d}_{6}\right) \delta: 12.66(\mathrm{~s}, 1 \mathrm{H}), 10.42(\mathrm{~s}, 2 \mathrm{H})$, $8.30(\mathrm{~d}, J=9.6 \mathrm{~Hz}, 1 \mathrm{H}), 8.11(\mathrm{~d}, J=6.9 \mathrm{~Hz}, 2 \mathrm{H}), 7.47(\mathrm{~d}, J=1.4 \mathrm{~Hz}, 1 \mathrm{H}), 7.43(\mathrm{~d}, J=4.9 \mathrm{~Hz}, 2 \mathrm{H}), 7.40$ $(\mathrm{s}, 1 \mathrm{H}), 7.21(\mathrm{~d}, J=16.3 \mathrm{~Hz}, 1 \mathrm{H}), 6.90(\mathrm{~d}, J=6.7 \mathrm{~Hz}, 2 \mathrm{H}), 6.70(\mathrm{~d}, J=16.4 \mathrm{~Hz}, 1 \mathrm{H}), 6.42(\mathrm{~s}, 1 \mathrm{H}), 6.17$ $(\mathrm{s}, 1 \mathrm{H}), 5.71(\mathrm{~d}, J=8.0 \mathrm{~Hz}, 1 \mathrm{H}), 5.07(\mathrm{~d}, J=18.5 \mathrm{~Hz}, 2 \mathrm{H}), 4.35(\mathrm{~s}, 1 \mathrm{H}), 3.89(\mathrm{dd}, J=18.5,9.7 \mathrm{~Hz}, 1 \mathrm{H}), 3.58$ $(\mathrm{d}, J=11.3 \mathrm{~Hz}, 1 \mathrm{H}), 3.43(\mathrm{~s}, 2 \mathrm{H}), 3.11(\mathrm{~s}, 2 \mathrm{H})$. HRMS (ESI): calcd. for $\left[\mathrm{M}-\mathrm{H}^{-} \mathrm{C}_{30} \mathrm{H}_{27} \mathrm{FNO}_{11^{-}}\right.$: 594.1412, found 594.1418. 
3-O-(2-deoxy-2-((3-(3-hydroxyphenyl)-1-oxo-2-propenyl)amino)- $\beta$-D-glucopyranosyl)-kaempferol (14d): Yellow solid, 35\% yield, m.p. 198.2-199.7 ${ }^{\circ} \mathrm{C} ;{ }^{1} \mathrm{H}-\mathrm{NMR}\left(600 \mathrm{MHz}, \mathrm{DMSO}-\mathrm{d}_{6}\right) \delta: 12.64(\mathrm{~s}, 1 \mathrm{H}), 11.16(\mathrm{~s}, 1 \mathrm{H})$, $10.42(\mathrm{~s}, 1 \mathrm{H}), 9.76(\mathrm{~s}, 1 \mathrm{H}), 8.31(\mathrm{~d}, J=9.1 \mathrm{~Hz}, 1 \mathrm{H}), 8.10(\mathrm{~d}, J=8.9 \mathrm{~Hz}, 2 \mathrm{H}), 7.31(\mathrm{~d}, J=15.7 \mathrm{~Hz}, 1 \mathrm{H}), 7.19$ $(\mathrm{t}, J=7.8 \mathrm{~Hz}, 1 \mathrm{H}), 6.97(\mathrm{~s}, 2 \mathrm{H}), 6.95(\mathrm{~s}, 1 \mathrm{H}), 6.92(\mathrm{~s}, 1 \mathrm{H}), 6.80(\mathrm{~d}, J=7.6 \mathrm{~Hz}, 1 \mathrm{H}), 6.59(\mathrm{~d}, J=15.8 \mathrm{~Hz}, 1 \mathrm{H})$, $6.51(\mathrm{~d}, J=1.9 \mathrm{~Hz}, 1 \mathrm{H}), 6.25(\mathrm{~d}, J=1.9 \mathrm{~Hz}, 1 \mathrm{H}), 5.68(\mathrm{~d}, J=8.4 \mathrm{~Hz}, 1 \mathrm{H}), 5.19(\mathrm{dd}, J=11.8,5.3 \mathrm{~Hz}, 2 \mathrm{H})$, $4.39(\mathrm{t}, J=5.6 \mathrm{~Hz}, 1 \mathrm{H}), 3.88(\mathrm{dd}, J=18.7,9.2 \mathrm{~Hz}, 1 \mathrm{H}), 3.55(\mathrm{~d}, J=5.1 \mathrm{~Hz}, 1 \mathrm{H}), 3.49-3.41(\mathrm{~m}, 2 \mathrm{H}), 3.10$ (s, 2H). HRMS (ESI): calcd. for $[\mathrm{M}+\mathrm{H}]^{+} \mathrm{C}_{30} \mathrm{H}_{28} \mathrm{NO}_{12}{ }^{+}: 594.1612$, found 594.1576.

3-O-(2-deoxy-2-((3-(4-trifluoromethylphenyl)-1-oxo-2-propenyl)amino)- $\beta$-D-glucopyranosyl)-kaempferol (14e): Yellow solid, 35\% yield, m.p. $178.8-180.1{ }^{\circ} \mathrm{C} ;{ }^{1} \mathrm{H}-\mathrm{NMR}\left(600 \mathrm{MHz}, \mathrm{DMSO}-\mathrm{d}_{6}\right) \delta: 12.66(\mathrm{~s}, 1 \mathrm{H}), 10.28(\mathrm{~s}, 2 \mathrm{H})$, $8.31(\mathrm{~d}, J=9.2 \mathrm{~Hz}, 1 \mathrm{H}), 8.12(\mathrm{~d}, J=8.9 \mathrm{~Hz}, 2 \mathrm{H}), 7.91(\mathrm{~s}, 1 \mathrm{H}), 7.88(\mathrm{~d}, J=7.8 \mathrm{~Hz}, 1 \mathrm{H}), 7.73(\mathrm{~d}, J=8.1 \mathrm{~Hz}$, $1 \mathrm{H}), 7.67(\mathrm{~d}, J=7.8 \mathrm{~Hz}, 1 \mathrm{H}), 7.51(\mathrm{~d}, J=15.8 \mathrm{~Hz}, 1 \mathrm{H}), 6.90(\mathrm{~d}, J=8.9 \mathrm{~Hz}, 2 \mathrm{H}), 6.80(\mathrm{~d}, J=15.9 \mathrm{~Hz}, 1 \mathrm{H})$, $6.41(\mathrm{~d}, J=1.9 \mathrm{~Hz}, 1 \mathrm{H}), 6.16(\mathrm{~d}, J=1.9 \mathrm{~Hz}, 1 \mathrm{H}), 5.71(\mathrm{~d}, J=8.4 \mathrm{~Hz}, 1 \mathrm{H}), 5.12(\mathrm{dd}, J=11.1,3.7 \mathrm{~Hz}, 2 \mathrm{H}), 4.34$ $(\mathrm{t}, J=5.2 \mathrm{~Hz}, 1 \mathrm{H}), 3.89(\mathrm{dd}, J=18.6,9.3 \mathrm{~Hz}, 1 \mathrm{H}), 3.58(\mathrm{dd}, J=11.2,4.5 \mathrm{~Hz}, 1 \mathrm{H}), 3.45(\mathrm{~m}, 2 \mathrm{H}), 3.12(\mathrm{~s}, 2 \mathrm{H})$. HRMS (ESI): calcd. for $[\mathrm{M}+\mathrm{H}]^{+} \mathrm{C}_{31} \mathrm{H}_{27} \mathrm{~F}_{3} \mathrm{NO}_{11}{ }^{+}:$: 646.1536, found 646.1522.

3-O-(2-deoxy-2-((3-(4-methoxylphenyl)-1-oxo-2-propenyl)amino)- $\beta$-D-glucopyranosyl)-kaempferol (14f): Yellow solid, 35\% yield, m.p. 177.9-179.6 ${ }^{\circ} \mathrm{C} ;{ }^{1} \mathrm{H}-\mathrm{NMR}\left(600 \mathrm{MHz}, \mathrm{DMSO}-\mathrm{d}_{6}\right) \delta: 12.67$ (s, 1H), $10.86(\mathrm{~s}, 1 \mathrm{H})$, $10.22(\mathrm{~s}, 1 \mathrm{H}), 8.16(\mathrm{~d}, J=9.4 \mathrm{~Hz}, 1 \mathrm{H}), 8.12(\mathrm{~d}, J=8.7 \mathrm{~Hz}, 2 \mathrm{H}), 7.51(\mathrm{~d}, J=8.5 \mathrm{~Hz}, 2 \mathrm{H}), 7.36(\mathrm{~d}, J=15.7 \mathrm{~Hz}$, $1 \mathrm{H}), 6.97(\mathrm{~d}, J=8.5 \mathrm{~Hz}, 2 \mathrm{H}), 6.90(\mathrm{~d}, J=8.7 \mathrm{~Hz}, 2 \mathrm{H}), 6.51(\mathrm{~d}, J=15.9 \mathrm{~Hz}, 1 \mathrm{H}), 6.43(\mathrm{~s}, 1 \mathrm{H}), 6.18(\mathrm{~s}, 1 \mathrm{H})$, $5.70(\mathrm{~d}, J=8.4 \mathrm{~Hz}, 1 \mathrm{H}), 5.09(\mathrm{~d}, J=5.9 \mathrm{~Hz}, 2 \mathrm{H}), 4.32(\mathrm{t}, J=5.0 \mathrm{~Hz}, 1 \mathrm{H}), 3.89(\mathrm{dd}, J=18.5,9.3 \mathrm{~Hz}, 1 \mathrm{H})$, $3.78(\mathrm{~s}, 3 \mathrm{H}), 3.58(\mathrm{dd}, J=10.9,4.8 \mathrm{~Hz}), 3.45-3.38(\mathrm{~m}, 2 \mathrm{H}), 3.11(\mathrm{~s}, 2 \mathrm{H})$. HRMS (ESI): calcd. for [M + H] ${ }^{+}$ $\mathrm{C}_{31} \mathrm{H}_{30} \mathrm{NO}_{12}^{+}$: 608.1768, found 608.1823.

\subsection{Biological Activity}

\subsubsection{Telomerase Activity Assays}

Compounds 5c, 6a-6c and 14a-14f were tested to search for inhibitors based on the structural framework of natural products with telomerase activity by using the TRAP-PCR assay. The idea is that if the compound does not inhibit telomerase activity at the labeled concentration, the number and intensity of ladders of the lane should be comparable to the positive control lane (as there is no inhibition, full-strength telomerase within cell lysate will lead to maximum number and intensity of ladders). If there is no lysate added, only the internal control band will be visible. A lane with potent inhibition will appear like the negative control lane. In detail, HeLa cells were first maintained in RPMI 1640 buffer, in which $10 \%$ fetal bovine serum was supplemented at $37^{\circ} \mathrm{C}$ in a humidified atmosphere containing $5 \% \mathrm{CO}_{2}$. After trypsinization, $2 \times 10^{5} \mathrm{HeLa}$ cells in the logarithmic growth phase were counted with a hemocytometer and collected in a tube, followed by incubation with baicalin and the drugs at a series of concentrations. After 24 h, $200 \mu \mathrm{L}$ of CHAPS lysis buffer was added to resuspend the cell pellet followed by incubation on ice for $30 \mathrm{~min}$. The cell suspension was centrifuged at 14,000 rpm for $20 \mathrm{~min}$ at $4{ }^{\circ} \mathrm{C}$, and the cell lysate (supernatant) was transferred to a new tube. The TRAP reaction was set up on ice in a $0.1 \mathrm{~mL}$ PCR tube. The reaction tube was incubated in 2720 Thermocycler (BioTek Instruments, Winooski, VT, USA) (Applied Biosystem) at $30{ }^{\circ} \mathrm{C}$ for $30 \mathrm{~min}$ to undergo TS extension followed by the $95^{\circ} \mathrm{C}$ heat inactivation of telomerase for $5 \mathrm{~min}$. Another reaction mix for the PCR was set up and subsequently added to the reaction tube. PCR was then initiated at $94{ }^{\circ} \mathrm{C}$ for $30 \mathrm{~s}, 60{ }^{\circ} \mathrm{C}$ for $30 \mathrm{~s}$, and $72{ }^{\circ} \mathrm{C}$ for $30 \mathrm{~s}$. The PCR products were analyzed by $12.5 \%$ nondenaturing gel electrophoresis in 0.5X TBE running buffer. The gel was stained with SYBR Green I Nuclei A (Invitrogen, Carlsbad, CA, USA) according to the manufacturer's instructions, and the results were obtained by autoradiography.

\subsubsection{Cell Proliferation Assays}

The antiproliferative activity of title compounds $5 c, 6 c, 14 b$ and $\mathbf{1 4} e$ against the five tumor cell lines (A549, HepG2, HeLa, MGC-803 and SGC-7901) as well as compound 5c against human normal cell 
lines (Hacat and BEAS-2B) were evaluated using a standard CCK-8-based colorimetric assay. All the above cell lines were provided by Jiangsu Keygen Biotech Co., Ltd. (Nanjing, China). In detail, target tumor cells were grown to the log phase in RPMI 1640 buffer, in which 10\% fetal bovine serum was supplemented, and dilution to $5.5 \times 10^{5}$ cells mL $\mathrm{m}^{-1}$ (A549, $4 \times 10^{4}$ cells mL ${ }^{-1}$ ) with complete medium. Then each well of 96-well culture plates added $100 \mu \mathrm{L}$ of the obtained cell suspension and placed in at $37^{\circ} \mathrm{C}$ in a $5 \% \mathrm{CO}_{2}$ atmosphere for $24 \mathrm{~h}$ for incubation before being subjected to the antiproliferation assessment. Then, $100 \mu \mathrm{L}$ of a series of concentrations of drug-containing medium were dispensed into wells to maintain final concentrations of $200,100,50,25,12.5,6.25,3.13,1.56$, and $0.78 \mu \mathrm{M}$. Each concentration was tested in triplicate, and 5-fluorouracil (5-FU) (Sigma-Aldrich, St. Louis, USA) was used as the positive control. After $48 \mathrm{~h}$ of incubation, cell survival was determined by the addition of $10 \mu \mathrm{L}$ of CCK-8 (BIOSHARP, 35002) working solution. After postincubation at $37^{\circ} \mathrm{C}$ for $3 \mathrm{~h}$, the plates were vortexed for $10 \mathrm{~min}$ to remove the air bubbles. The optical absorbance was measured at $450 \mathrm{~nm}$ with a microplate reader (BioTek Instruments, Winooski, VT, USA, EL-x800). The data represented the mean of three independent experiments in triplicate and were expressed as mean $\pm \mathrm{SD}$. The $\mathrm{IC}_{50}$ value was defined as the concentration at which $50 \%$ of the cells could survive. The $\mathrm{IC}_{50}$ values were calculated by fitting with the three-parameter Hill equation, with SPSS Statistics 19 where y is percent inhibition, $\mathrm{x}$ is inhibitor concentration, $\mathrm{n}$ is the slope of the concentration-response curve (Hill slope), and $\mathrm{V}_{\max }$ is maximal inhibition from three independent assays.

$$
\mathrm{y}=\mathrm{V}_{\max }\left(\frac{\mathrm{x}^{\mathrm{n}}}{\mathrm{IC}_{50}{ }^{\mathrm{n}}+\mathrm{x}^{\mathrm{n}}}\right)
$$

\subsection{Molecular Simulation Assays}

\subsubsection{Molecular Docking}

All ligand structures were prepared by Maestro 9.0 within the Schrödinger package. The 3D structures of all the studied compounds were created with Marvin sketch, and the initial lowest energy conformations were calculated with LigPrep. For protein preparation, the crystal structure coordinates of the human telomerase holoenzyme were obtained from the reference and then prepared with the Protein Preparation Wizard. All hydrogen atoms were added. The protein structure was then aligned with a similar protein discovered from another species to confirm the binding site (PDB:5CQG). Subsequently, the OPLS_2005 force field was used to optimize the protein energy and eliminate steric hindrance. For all dockings, the grid center was placed at the centroid of the ligand-binding site, and a $24 \times 24 \times 24 \AA$ Arid box size was used. All dockings were performed with Glide using the XP protocol. The docking poses were analyzed by PyMOL [28].

\subsubsection{Simulations}

Compounds 5c, $\mathbf{6 c}$ and BIBR1532 were used to form three complexes with the protein refer to the molecular docking results. By using the Desmond 2014.2 software (Schrodinger, Harrison, NYC, USA) suite (D. E. Shaw Research), all-atom (OPLS3 force field) explicit water MD simulations for each researched compound were performed via Maestro MD systems and were built with the use of the highest-scoring docking pose. Specifically, the coordinate files of the human telomerase holoenzyme were obtained from the reference. An orthorhombic box with a boundary distance of $10 \AA$ was generated to define the binding pocket. During the simulation, the Desmond default OPLS3 force field was used. All the $100 \mathrm{~ns}$ simulations were run on our servers [29,30]. Moreover, the RMSD, RMSF and ligand-protein interaction were monitored to determine the stability of the docking complexes.

\section{Conclusions}

In this study, twelve novel flavonoid derivatives were designed and synthesized, and ten were evaluated as potential telomerase inhibitors. It was surprising that compound $5 \mathrm{c}$ showed high 
inhibitory activity against telomerase with an $\mathrm{IC}_{50}<50 \mu \mathrm{M}$. Moreover, compound $5 \mathrm{c}$ exhibited potent broad-spectrum anticancer activity against the A549, HepG2, HeLa, MGC-803 and SGC-7901 cell lines in vitro. The binding modes of BIBR1532 and compound $5 \mathrm{c}$ to telomerase indicated that the conserved residues Lys 437 and Asn 421 were important for ligand binding via hydrogen bonding interactions, which could explain the SAR of these compounds and match the active in vitro data. These results help the reasonable design of the more potent telomerase inhibitors based on the structural scaffolds of natural products for cancer therapy.

Supplementary Materials: The ${ }^{1} \mathrm{H}-\mathrm{NMR}$ spectra of compounds $\mathbf{5 a - 5 c}, \mathbf{6 a}-\mathbf{6 c}$ and $\mathbf{1 4 a}-\mathbf{1 4 f}$ are available online at Figures S1-S12.

Author Contributions: M.-S.C, Y.L. and P.-C.S. supervised the whole experiment and provided technical guidance. Z.-F.F. designed and synthesized all of the novel compounds. S.-T.H. and C.H. assisted in biology research. Y.F. and L.Z. assisted in the synthesis. R.W. and J.W. supervised and carried out molecular modeling experiments.

Funding: The authors gratefully acknowledge the National Natural Science Foundation of China (No. 81473087), the Program for Liaoning Innovative Talents in University (LR2017043), and the Career Development Support Plan for Young and Middle-aged Teachers in Shenyang Pharmaceutical University (ZQN2016005) for the financial support.

Conflicts of Interest: The authors declare no conflict of interest.

\section{References}

1. Elshemy, H.A.H.; Zaki, M.A. Design and synthesis of new coumarin hybrids and insight into their mode of antiproliferative action. Bioorg. Med. Chem. 2017, 25, 1066-1075. [CrossRef] [PubMed]

2. Bray, F.; Ferlay, J.; Soerjomataram, I.; Siegel, R.L.; Torre, L.A.; Jemal, A. Global cancer statistics 2018: GLOBOCAN estimates of incidence and mortality worldwide for 36 cancers in 185 countries. CA Cancer. J. Clin. 2018, 68, 394-424. [CrossRef] [PubMed]

3. Kim, N.W.; Piatyszek, M.A.; Prowse, K.R.; Harley, C.B.; West, M.D.; Ho, P.L.; Coviello, G.M.; Wright, W.E.; Weinrich, S.L.; Shay, J.W. Specific association of human telomerase activity withimmortal cells and cancer. Science 1994, 266, 2011-2015. [CrossRef] [PubMed]

4. Wang, Y.; Cheng, F.X.; Yuan, X.L.; Tang, W.J.; Shi, J.B.; Liao, C.Z.; Liu, X.H. Dihydropyrazole derivatives as telomerase inhibitors: Structure-based design, synthesis, SAR and anticancer evaluation in vitro and in vivo. Eur. J. Med. Chem. 2016, 112, 231-251. [CrossRef] [PubMed]

5. Ganesan, K.; Xu, B. Telomerase inhibitors from natural products and their anticancer potential. Int. J. Mol. Sci. 2017, 19, 13. [CrossRef] [PubMed]

6. De, C.A.; Lacroix, L.; Douarre, C.; Temime-Smaali, N.; Trentesaux, C.; Riou, J.F.; Mergny, J.L. Targeting telomeres and telomerase. Biochimie 2008, 90, 131-155.

7. Sun, D.; Thompson, B.; Cathers, B.E.; Salazar, M.; Kerwin, S.M.; Trent, J.O.; Jenkins, T.C.; Neidle, S.; Hurley, L.H. Inhibition of human telomerase by a G-quadruplex-interactive compound. J. Med. Chem. 1997, 40, 2113-2116. [CrossRef]

8. Paul, A.; Maji, B.; Misra, S.K.; Jain, A.K.; Muniyappa, K.; Bhattacharya, S. Stabilization and structural alteration of the G-quadruplex DNA made from the human telomeric repeat mediated by Troger's base based novel benzimidazole derivatives. J. Med. Chem. 2012, 55, 7460-7471. [CrossRef]

9. Tang, W.J.; Wang, J.; Tong, X.; Shi, J.B.; Liu, X.H.; Li, J. Design and synthesis of celastrol derivatives as anticancer agents. Eur. J. Med. Chem. 2015, 95, 166-173. [CrossRef]

10. Lee, C.C.; Huang, K.F.; Lin, P.Y.; Huang, F.C.; Chen, C.L.; Chen, T.C.; Guh, J.H.; Lin, J.J.; Huang, H.S. Synthesis, antiproliferative activities and telomerase inhibition evaluation of novel asymmetrical 1,2-disubstituted amidoanthraquinone derivatives. Eur. J. Med. Chem. 2012, 47, 323-336. [CrossRef]

11. Zheng, D.S.; Chen, L.S. Triterpenoids from Ganoderma lucidum inhibit the activation of EBV antigens as telomerase inhibitors. Exp. Ther. Med. 2017, 14, 3273-3278. [CrossRef] [PubMed]

12. Imad Naasani, F.O.; Tomoko, O.; Wan, Y.F.; Johnston, J.; Chan, K.; Tsuruo, T. Blocking telomerase by dietary polyphenols is a major mechanism for limiting the growth of human cancer cells in vitro and in vivo. Cancer Res. 2003, 63, 824-830. 
13. Menichincheri, M.; Ballinari, D.; Bargiotti, A.; Bonomini, L.; Ceccarelli, W.; D’Alessio, R.; Fretta, A.; Moll, J.; Polucci, P.; Soncini, C.; et al. Catecholic flavonoids acting as telomerase inhibitors. J. Med. Chem. 2004, 47, 6466-6475. [CrossRef] [PubMed]

14. Rao, Y.K.; Kao, T.Y.; Wu, M.F.; Ko, J.L.; Tzeng, Y.M. Identification of small molecule inhibitors of telomerase activity through transcriptional regulation of hTERT and calcium induction pathway in human lung adenocarcinoma A549 cells. Bioorg. Med. Chem. 2010, 18, 6987-6994. [CrossRef] [PubMed]

15. Xue, W.; Song, B.A.; Zhao, H.J.; Qi, X.B.; Huang, Y.J.; Liu, X.H. Novel myricetin derivatives: Design, synthesis and anticancer activity. Eur. J. Med. Chem. 2015, 97, 155-163. [CrossRef]

16. Hou, Z.; Lin, B.; Bao, Y.; Yan, H.N.; Zhang, M.; Chang, X.W.; Zhang, X.X.; Wang, Z.J.; Wei, G.F.; Cheng, M.S.; et al. Dual-tail approach to discovery of novel carbonic anhydrase IX inhibitors by simultaneously matching the hydrophobic and hydrophilic halves of the active site. Eur. J. Med. Chem. 2017, 132, 1-10. [CrossRef] [PubMed]

17. Thirumurugan, P.; Matosiuk, D.; Jozwiak, K. Click chemistry for drug development and diverse chemical-biology applications. Chem. Rev. 2013, 113, 4905-4979. [CrossRef] [PubMed]

18. Tian, Y.; Liu, W.; Lu, Y.; Wang, Y.; Chen, X.; Bai, S.; Zhao, Y.; He, T.; Lao, F.; Shang, Y.; et al. Naturally occurring cinnamic acid sugar ester derivatives. Molecules 2016, 21, 1402-1449. [CrossRef] [PubMed]

19. Sova, M. Antioxidant and antimicrobial activities of cinnamic acid derivatives. Mini. Rev. Med. Chem. 2012, 12, 749-767. [CrossRef]

20. De, P.; Bedos-Belval, F.; Vanucci-Bacque, C.; Baltas, M. Cinnamic acid derivatives in tuberculosis, malaria and cardiovascular diseases-A Review. Cur. Org. Chem. 2012, 16, 747-768.

21. Sharma, P. Cinnamic acid derivatives: A new chapter of various pharmacological activities. J. Chem. Pharm. Res. 2011, 3, 403-423.

22. Li, H.N.; Wang, H.; Wang, Z.P.; Yan, H.N.; Zhang, M.; Liu, Y.; Cheng, M.S. Synthesis, antitumor activity evaluation and mechanistic study of novel hederacolchiside A1 derivatives bearing an aryl triazole moiety. Bioorg. Med. Chem. 2018, 26, 4025-4033. [CrossRef] [PubMed]

23. Wei, G.F.; Wang, S.; Luan, W.J.; Cui, S.S.; Li, F.R.; Liu, Y.X.; Liu, Y.; Cheng, M.S. A library of 1,2,3-triazole-substituted oleanolic acid derivatives as anticancer agents: Design, synthesis, and biological evaluation. Org. Biomol. Chem. 2015, 13, 1507-1514. [CrossRef] [PubMed]

24. Wei, G.; Cui, S.; Luan, W.; Wang, S.; Hou, Z.; Liu, Y.; Liu, Y.; Cheng, M. Natural product-based design, synthesis and biological evaluation of Albiziabioside A derivatives that selectively induce HCT116 cell death. Eur. J. Med. Chem. 2016, 113, 92-101. [CrossRef] [PubMed]

25. Wei, G.; Sun, J.; Hou, Z.; Luan, W.; Wang, S.; Cui, S.; Cheng, M.; Liu, Y. Novel antitumor compound optimized from natural saponin Albiziabioside A induced caspase-dependent apoptosis and ferroptosis as a p53 activator through the mitochondrial pathway. Eur. J. Med. Chem. 2018, 157, 759-772. [CrossRef] [PubMed]

26. Nguyen, T.H.D.; Tam, J.; Wu, R.A.; Greber, B.J.; Toso, D.; Nogales, E.; Collins, K. Cryo-EM structure of substrate-bound human telomerase holoenzyme. Nature 2018, 557, 190-195. [CrossRef]

27. Bryan, C.; Rice, C.; Hoffman, H.; Harkisheimer, M.; Sweeney, M.; Skordalakes, E. Structural Basis of Telomerase Inhibition by the Highly Specific BIBR1532. Structure 2015, 23, 1934-1942. [CrossRef]

28. Wang, M.; Wang, Y.; Kong, D.; Jiang, H.; Wang, J.; Cheng, M. In silico exploration of aryl sulfonamide analogs as voltage-gated sodium channel 1.7 inhibitors by using 3D-QSAR, molecular docking study, and molecular dynamics simulations. Comput. Biol. Chem. 2018, 77, 214-225. [CrossRef]

29. Wang, Y.; Hu, B.; Peng, Y.; Xiong, X.; Jing, W.; Wang, J.; Gao, H. In Silico Exploration of the Molecular Mechanism of Cassane Diterpenoids on Anti-inflammatory and Immunomodulatory Activity. J. Chem. Inf. Model. 2019, 59, 2309-2323. [CrossRef]

30. Wang, M.; Li, W.; Wang, Y.; Song, Y.; Wang, J.; Cheng, M. In silico insight into voltage-gated sodium channel 1.7 inhibition for anti-pain drug discovery. J. Mol. Graph. Model. 2018, 84, 18-28. [CrossRef]

Sample Availability: Samples of the compounds 5a-5c, $\mathbf{6 a - 6 c}$ and $\mathbf{1 4 a - 1 4 f}$ are available from the authors. 